\title{
HUBUNGAN PERILAKU MEROKOK ORANG TUA DENGAN KEJADIAN INFEKSI SALURAN PERNAPASAN AKUT PADA BALITA DI UPTD PUSKESMAS TABANAN III
}

\author{
RELATIONSHIP OF PARENTS SMOKING BEHAVIOR \\ WITH THE EVENT OF ACUTE RESPIRATORY \\ INFECTION IN INFANTS AT TABANAN UPTD \\ PUSKESMAS III
}

\author{
Ni Made Heni Wahyuni ${ }^{1}$, Ni Ketut Ayu Mirayanti ${ }^{2}$, Niken Ayu Merna Eka Sari ${ }^{3}$ \\ Sekolah Tinggi Ilmu Kesehatan Wira Medika Bali ${ }^{1,2,3}$
}

\begin{abstract}
ABSTRAK
Penyakit Infeksi Saluran Pernapasan Akut menyumbang 16\% dari seluruh kematian anak di dunia usia dibawah 5 tahun yang menyebabkan kematian pada 920.136 balita. Kejadian infeksi saluran pernapasan akut pada balita disebabkan oleh faktor demografi, faktor biologis dan faktor polusi yang berupa perilaku merokok. Paparan asap rokok pada anak dari orang tua menjadikan anak terpapar dengan asap berbahaya yang dapat mengganggu saluran napasnya. Tujuan dari penelitian ini adalah untuk mengetahui hubungan perilaku merokok orangtua dengan kejadian infeksi saluran pernafasan akut pada balita di UPTD Puskesmas Tabanan III. Desain penelitian yang digunakan adalah analitik korelasi dengan pendekatan cross sectional. Sampel penelitian berjumlah 68 orang dengan teknik sampel purposive sampling. Data dikumpulkan dengan kuesioner dan lembar observasi dengan uji statistik Chi Square. Hasil penelitian didapatkan dari 68 responden, sebesar $75 \%$ orang tua merokok dan kejadian ISPA pada balita sebesar $63,2 \%$. Hasil analisis menunjukkan adanya hubungan antara perilaku merokok orang tua dengan kejadian ISPA pada balita di UPTD Puskesmas Tabanan III. Disarankan kepada tenaga kesehatan dapat meningkatkan kegiatan sosialisasi dan edukasi tentang bahaya merokok bagi balita
\end{abstract}

Kata Kunci : Perilaku Merokok Orang Tua, Infeksi Saluran Pernapasan Akut, Balita

\section{ABSTRACT}

The Acute Respiratory Infection contributes $16 \%$ from all children death at the age of under five years which cause the the death on 920.136 children under five years. Occurrence of Acute Respiratory Infection of the children under 5 years is caused by demographic factor, biological factor, and pollution factor in the form of smoking behavior. The expose of cigarette smoke to the children from their parents makes them are exposed to dangerous smoke which can disturb their respiratory. The aim of this research is to determine the correlation between smoking behavior with the incidence of acute respiratory infection of infant at UPTD Puskesmas Tabanan III. The design of this research is analytic correlation with cross sectional. The number of samples are 68 children under five years by using purposive sampling. The data was collected by 
Bali Medika Jurnal.

Vol 7 No 1, 2020: 11-23

ISSN : 2615-7047

DOI: https://doi.org/10.36376/bmj.v7i1

questionnaire and observation and analyzed by statistical test Chi Square. The result shows from 68 respondents $75 \%$ of parents are smokers and the number of incidence of acute respiratory infections of children under 5 years is $63,2 \%$ The result of this analysis shows there is a correlation between smoking behavior of parents with the incidence of acute respiratory infection infants at UPTD Puskesmas Tabanan III. It is suggested healh officers to raise activities to socialize and educate about the danger of smoking cigarettes to the children under 5 years.

Keywords: Smoking Behavior Of Parents, Incidence Of Acute Respirotary, Infants

\begin{tabular}{ll}
\hline Alamat Korespondensi & $\begin{array}{l}\text { : Jl. Kecak No.9A, Tonja, Kec. Denpasar Utara, Kota Denpasar, } \\
\text { Bali } 80239\end{array}$ \\
Email & : madeheniwahyuni@gmail.com \\
\hline
\end{tabular}

\section{PENDAHULUAN}

Perilaku adalah suatu tindakan yang dapat diamati dan mempunyai frekuensi yang spesifik, durasi dan tujuan baik disadari atau tidak (Wawan \& Dewi, 2012). Perilaku merokok merupakan respons seseorang terhadap rangsangan dari luar yaitu berupa faktor-faktor yang mempengaruhi seseorang untuk merokok dan dapat diamati secara langsung (Santoso, 2015). Merokok merupakan sebuah kebiasaan memberikan kenikmatan bagi si perokok, namun dapat menimbulkan dampak buruk bagi si perokok atau orang-orang disekitarnya (Novita dan Franciska, 2011). Asap rokok yang berasal dari perokok mengandung zat-zat yang berbahaya bagi kesehatan tubuh. Asap rokok yang berlebihan dapat merusak sel paru-paru baik sel saluran pernapasan maupun sel jaringan paru seperti alveoli (Winarmi, Ummah \& Salim, 2009). Di Indonesia, perilaku merokok dijumpai pada usia muda atau perokok pemula $\leq 18$ tahun dan tertinggi pada orang tua usia 40-49 tahun (Kementerian Kesehatan RI, 2017). Orang tua merupakan ayah dan/atau ibu dari seorang anak, baik dengan hubungan biologis maupun sosial. Orang tua adalah orang yang lebih tua atau orang yang dituakan, terdiri dari ayah dan ibu yang merupakan guru dan contoh utama untuk anak-anaknya (Friedman et al., 2010). Kebiasaan orang tua yang merokok di dalam rumah dapat berdampak negatif bagi anggota keluarga dan anak-anak khususnya balita (Riyanto \& Kusumawati, 2016). Balita merupakan sebutan untuk anak usia 1-3 tahun (toodler) dan 4-5 tahun (preschool). Pada usia ini merupakan masa yang berlangsung cepat dan tidak akan terulang kembali sehingga sering disebut golden age atau masa keemasan. Masa balita merupakan periode yang sangat penting dalam proses tumbuh kembang seorang manusia. Pertumbuhan dan perkembangan dimasa itu menjadi penentu keberhasilan pertumbuhan dan perkembangan anak diperiode selanjutnya (Sutomo \& Anggraini, 2010). Para ahli menggolongkan usia balita sebagai tahapan perkembangan anak yang cukup rentan terhadap serangan penyakit karena sistem pertahanan tubuh pada balita masih dalam tahap perkembangan (Wijayaningsih, 2013). Penyakit yang banyak diderita anak balita adalah diare, demam tifoid, pneumonia, dan salah satunya infeksi saluran pernafasan akut (ISPA) (Kementerian Kesehatan RI, 2013).

Infeksi Saluran Pernapasan Akut (ISPA) adalah infeksi akut yang menyerang salah satu bagian atau lebih dari saluran napas mulai hidung sampai alveoli 
termasuk adneksanya (sinus, rongga telinga tengah, pleura) (Ditjen P2PL, 2011). Anak-anak yang orang tuanya perokok lebih mudah terkena penyakit saluran pernapasan seperti flu, asma, pneumonia, ISPA dan penyakit saluran pernapasan lainnya. Sebanyak 40 persen anak di dunia bahkan telah menjadi perokok pasif. Gas berbahaya yang terkandung didalam asap rokok dapat merangsang pembentukan lendir, debu dan bakteri yang tertumpuk dan tidak dapat dikeluarkan, yang akan menyebabkan timbulnya bronchitis kronis, lumpuhnya serat elastin di jaringan paru sehingga mengakibatkan daya pompa paru berkurang, udara tertahan di paru-paru dan mengakibatkan pecahnya kantong udara.

Menurut WHO, infeksi saluran pernapasan akut menyumbang 16\% dari seluruh kematian anak di dunia usia dibawah 5 tahun yang menyebabkan kematian pada 920.136 balita. Berdasarkan data Laporan Rutin Subdit ISPA Tahun 2017, didapatkan insiden ISPA (per 1000 balita) di Indonesia sebesar 20,54\%. Angka kematianakibatinfeksi saluran pernapasan akut padabalitatahun2016 sebesar0,22\% pada tahun 2017 menjadi 0.34\% (Kementerian Kesehatan RI, 2017). Menurut data SIRS, pada pasien rawat jalan penyakit yang banyak diderita anak balita yaitu infeksi saluran pernapasan akut sebesar 86.150 jiwa (Kementerian Kesehatan RI, 2013). Pada tahun 2018, di Provinsi Bali penyakit ISPA tercatat sebanyak 193.250 kasus. Di Kabupaten Tabanan, kasus ISPA tahun 2017 sebesar 29.176 kasus dan mengalami peningkatan pada tahun 2018 sebanyak 30.178 kasus (Dinas Kesehatan Kabupaten Tabanan, 2017).

Menurut data dari IDAI (2016), sebanyak 165.000 orang anak di dunia meninggal setiap tahun karena penyakit paru terkait dengan paparan asap rokok. Menurut Kementerian Kesehatan RI (2014), presentase seorang perokok di ASEAN tersebar di Indonesia (46,16\%), Filipina (16,62\%), Vietnam (14,11\%), Myanmar $(8,73 \%)$, Thailand (7,74\%), Malaysia (2,90\%), Kamboja (2,07\%), Laos (1,23\%), Singapura $(0,39 \%)$ dan Brunei $(0,04 \%)$. Berdasarkan data hasil Survei Indikator Kesehatan Nasional (SIRKESNAS) pada tahun 2016, prevalensi merokok nasional adalah 28,5\%. Prevalensi merokok berdasarkan jenis kelamin, ditemukan prevalensi pada laki-laki 59\% dan perempuan 1,6\%. Menurut kelompok umur, prevalensi tertinggi pada usia 40-49 tahun sebesar 39,5\% sedangkan pada usia muda atau perokok pemula $\leq 18$ tahun sebesar 8,8\% (Kementerian Kesehatan RI, 2017). Prevalensi merokok berdasarkan kelompok umur di Provinsi Bali, 3 kabupaten tertinggi yaitu Kabupaten Jembrana, Kabupaten Tabanan dan Kabupaten Buleleng. Berdasarkan hasil survei tentang Kawasan Tanpa Rokok tahun 2016 di Provinsi Bali jumlah perokok menurut kabupaten/kota adalah Jembrana 77,2\%, Tabanan 76,5\% dan Kabupaten Buleleng 67,3\% (Dinas Kesehatan Provinsi Bali, 2016).

Menurut penelitian Lebuan \& Somia (2014), asap rokok baik dari orang tua atau penghuni rumah satu atap dapat mencemari udara, dan apabila terhirup oleh anak dapat merusak pertahanan saluran pernapasan, sehingga patogen penyebab ISPA mudah masuk dan menginfeksi anak yang menimbulkan manifestasi klinis ISPA. Berdasarkan hasil penelitian Milo, Ismanto, \& Kallo, (2015), didapatkan pada orang tua perokok berat ada 12 dari $22(54,5 \%)$ anaknya yang menderita ISPA sedang, pada orang tua perokok sedang ada 5 dari $14(35,7 \%)$ anaknya yang menderita ISPA sedang. Tujuan penelitian ini adalah untuk mengetahui hubungan perilaku merokok orang tua dengan kejadian infeksi saluran pernafasan akut pada balita di UPTD Puskesmas Tabanan III. 


\section{METODE DAN BAHAN}

Penelitian ini merupakan jenis penelitian analitik korelasi yang bertujuan dengan pendekatan yang digunakan cross sectional. Penelitian ini dilaksanakan di UPTD Puskesmas Tabanan III pada tanggal 4 September- 4 Oktober 2019. Populasi dalam penelitian ini adalah semua balita yang berobat di UPTD Puskesmas Tabanan III selama tiga bulan terakhir yaitu bulan Mei, Juni dan Juli tahun 2019 dengan total 81 orang. Teknik pengambilan sampel dalam penelitian ini adalah purposive sampling dengan besar sampel yang yang memenuhi kriteria inklusi dan eksklusi yaitu sebanyak 68 orang. Teknik analisa data yang digunakan untuk menguji hubungan dalam penelitian ini adalah uji Chi Square (derajat kepercayaan 95\% ( $\alpha$ $=0.05)$.

\section{HASIL}

\section{HASIL DAN PEMBAHASAN}

Tabel 1 Distribusi Frekuensi Jenis Kelamin Responden Pada Orang Tua Yang Memiliki Balita Di UPTD Puskesmas Tabanan III

\begin{tabular}{cccc}
\hline No & Jenis Kelamin & Frekuensi (f) & Presentase (\%) \\
\hline 1 & Laki-laki & 65 & 95,6 \\
2 & Perempuan & 3 & 4,4 \\
\hline Jumlah & & 68 & 100 \\
\hline
\end{tabular}

Berdasarkan tabel 1 diketahui mayoritas responden berjenis kelamin laki-laki yaitu sebanyak 65 orang $(95,6 \%)$.

Tabel 2. Distribusi Frekuensi Usia Responden Pada Orang Tua Yang Memiliki Balita Di UPTD Puskesmas Tabanan III

\begin{tabular}{cccc}
\hline No & Usia & Frekuensi (f) & Presentase (\%) \\
\hline 1 & 21-30 Tahun & 19 & 27,9 \\
2 & 31-40 Tahun & 40 & 58,8 \\
3 & 41-50 Tahun & 9 & 13,2 \\
\hline Jumlah & & 68 & 100 \\
\hline
\end{tabular}

Berdasarkan tabel 2 diketahui mayoritas responden berusia 31-40 tahun yaitu sebanyak 40 orang $(58,8 \%)$.

Tabel 3. Distribusi Frekuensi Tingkat Pendidikan Pada Orang Tua Yang Memiliki Balita Di UPTD Puskesmas Tabanan III

\begin{tabular}{cccc}
\hline No & Tingkat Pendidikan & Frekuensi (f) & Presentase (\%) \\
\hline 1 & Tidak Tamat SD & 0 & 0 \\
2 & SD & 0 & 0 \\
3 & SMP & 4 & 5,9 \\
4 & SMA & 45 & 66,2 \\
5 & Perguruan Tinggi & 19 & 27,9 \\
\hline Jumlah & & 68 & 100 \\
\hline
\end{tabular}


Berdasarkan tabel 3 diketahui mayoritas responden berpendidikan SMA yaitu sebanyak 45 orang $(66,2 \%)$.

Tabel 4. Distribusi Frekuensi Pekerjaan Responden Pada Orang Tua Yang Memiliki Balita Di UPTD Puskesmas Tabanan III

\begin{tabular}{cccc}
\hline No & Pekerjaan & Frekuensi (f) & Presentase (\%) \\
\hline 1 & Tidak Tamat Bekerja & 0 & 0 \\
2 & Buruh & 7 & 10,3 \\
3 & Pegawai Swasta & 32 & 47,1 \\
4 & Wiraswasta & 25 & 36,8 \\
5 & PNS & 4 & 5,9 \\
\hline Jumlah & & 68 & 100 \\
\hline
\end{tabular}

Berdasarkan tabel 4 diketahui mayoritas responden bekerja sebagai pegawai swasta yaitu sebanyak 32 orang $(47,1 \%)$.

Tabel 5 Hasil Pengamatan Perilaku Merokok Orang Tua di UPTD Puskesmas Tabanan III

\begin{tabular}{cccc}
\hline No & Merokok & Frekuensi (f) & Presentase (\%) \\
\hline 1 & Merokok & 51 & 75 \\
2 & Tidak Merokok & 17 & 25 \\
\hline Jumlah & & 68 & 100,0 \\
\hline
\end{tabular}

Berdasarkan tabel 5 didapatkan hasil dari 68 responden, mayoritas reponden merokok yaitu sebanyak 51 orang $(75 \%)$.

Tabel 6 Hasil Pengamatan Kejadian Infeksi Saluran Pernapasan Akut Pada Balita Di Puskesmas Tabanan III

\begin{tabular}{cccc}
\hline No & ISPA & Frekuensi (f) & Presentase (\%) \\
\hline 1 & ISPA & 43 & 63,2 \\
2 & Tidak ISPA & 25 & 36,8 \\
\hline Jumlah & & 68 & 100,0 \\
\hline
\end{tabular}

Berdasarkan tabel 4.6 didapatkan hasil dari 68 responden, mayoritas ISPA yaitu sebanyak 43 orang $(63,2 \%)$.

Tabel 7 Hubungan Perilaku Merokok Dengan Kejadian Infeksi Saluran Pernapasan Akut Pada Balita Di UPTD Puskesmas Tabanan III

\begin{tabular}{ccccccccc} 
No & Perilaku & \multicolumn{4}{c}{ Kejadian ISPA Pada } & \multirow{2}{*}{ Total } & Asymp. Sig \\
& Merokok & \multicolumn{2}{c}{ BSPA } & \multicolumn{2}{c}{ Tidak ISPA } & & & \\
& & ISPided) & & & \\
& & f & $\%$ & f & $\%$ & f & $\%$ & \\
\hline 1 & Merokok & 36 & 52,9 & 15 & 22,1 & 51 & 75 & \\
2 & Tidak & 7 & 10,3 & 10 & 14,7 & 17 & 25 & 0,029 \\
& Merokok & & & & & & & \\
\hline Jumlah & & 43 & 63,2 & 25 & 36,8 & 68 & 100 & \\
\hline
\end{tabular}


Berdasarkan tabel 4.7 dari hasil uji Chi Square diperoleh nilai Asymp. Sig (2-sided) adalah $0,029<\mathrm{a}(0,05)$ yang berarti Ho ditolak dan Ha diterima sehingga terdapat hubungan antara perilaku merokok orang tua dengan kejadian infeksi saluran pernapasan akut pada balita di UPTD Puskesmas Tabanan III.

\section{PEMBAHASAN}

\section{Perilaku Merokok pada Orang Tua Balita di UPTD Puskesmas Tabanan III}

Hasil penelitian ini sejalan dengan penelitian Asmidar (2018) dengan judul "Hubungan Kebiasaan Merokok Anggota Keluarga Di Dalam Rumah Dengan Kejadian ISPA Pada Anak Usia 1-5 Tahun Di Puskesmas Asinua Kabupaten Konawe Tahun 2018" yang menyatakan bahwa kebiasaan merokok keluarga di dalam rumah sebanyak 34 responden (100\%) dengan kejadian ISPA pada anak usia 1-5 tahun mengalami ISPA sebanyak 25 orang $(73,5 \%)$ dan tidak terjadi ISPA sebanyak 9 orang (26,5\%). Hasil penelitian ini sejalan dengan penelitian Milo, Ismanto \& Kallo (2015) dengan judul "Hubungan Kebiasaan Merokok di Dalam Rumah Dengan Kejadian ISPA Pada Anak Umur 1-5 Tahun Di Puskesmas Sario Kota Manado" yang menyatakan pada orang tua yang perokok berat ada 12 dari 22 anak $(54,5 \%)$ anak menderita ISPA sedang, dan pada orang tua perokok sedang ada 5 dari 14 anak $(35,7 \%)$ anak menderita ISPA sedang.

Penelitian ini juga sejalan dengan penelitian Wahyuningsih, Raodhah \& Basri (2017) dengan judul "Infeksi Saluran Pernapasan Akut (ISPA) Pada Balita Di Wilayah Pesisir Desa Kore Kecamatan Sanggar Kabupaten Bima" yang menyatakan bahwa terdapat anggota keluarga yang merokok sebanyak 32 responden $(43,35 \%)$ dan rata-rata tempat merokok anggota keluarga adalah didalam rumah. Hasil penelitian ini sesuai dengan teori Santoso (2015) yang menyatakan bahwa perilaku merokok adalah aktivitas seseorang yang merupakan respons seseorang terhadap rangsangan dari luar yaitu faktor-faktor yang mempengaruhi seseorang untuk merokok dan dapat diamati secara langsung. Teori Corwin (2009) menyatakan anak yang terpajan asap rokok memperlihatkan peningkatan angka ISPA dan penyakit saluran pernapasan lainnya dibandingkan dengan anak-anak dari orang tua bukan perokok.

Berdasarkan hasil penelitian yang dilakukan didapatkan bahwa mayoritas responden berjenis kelamin laki-laki yaitu sebanyak 65 orang $(95,6 \%)$. Penelitian ini sejalan dengan penelitian Rahayu, Yuniar \& Fachlevy (2017) dengan judul "Faktor Yang Berhubungan Dengan Kejadian ISPA Pada Balita Di Wilayah Kerja Puskesmas Soropia Kabupaten Konawe Tahun 2017" yang menyatakan bahwa 53 $(63,1 \%)$ responden memiliki anggota keluarga yang merokok yang didominasi oleh laki-laki. Penelitian ini juga sejalan dengan penelitian Junita (2015) yang berjudul "Hubungan Antara Status Merokok Anggota Keluarga Dengan Status ISPA Pada Balita Di Kelurahan Pahandut Kota Palangkaraya" yang menyatakan bahwa 54 (78,3\%) anggota keluarga yang merokok yang sebagian besar adalah ayah balita. Penelitian ini juga sejalan dengan penelitian Rohim (2014) yang berjudul "Hubungan Merokok Anggota Keluarga Dengan Kejadian Infeksi Saluran Pernapasan Akut (ISPA) Pada Balita Di Wilayah Kerja Puskesmas Paciran Kabupaten Lamongan" yang menyatakan sebagian besar keluarga merokok sebanyak 23 orang $(65,7 \%)$ yaitu kepala keluarga sebagai perokok aktif. Penelitian ini sesuai dengan teori Sarafino (dalam Sulistyawan, 2012) yang menyatakan faktor 
yang mempengaruhi merokok adalah jenis kelamin. Pada perilaku merokok ditemukan lebih dominan pada laki-laki daripada perempuan.

Berdasarkan hasil penelitian, diperoleh data bahwa mayoritas responden berusia 31-40 tahun sebanyak 40 orang (58,8\%). Penelitian ini tidak sejalan dengan penelitian Milo, Ismanto \& Kallo (2015) dengan judul "Hubungan Kebiasaan Merokok di Dalam Rumah Dengan Kejadian ISPA Pada Anak Umur 1-5 Tahun Di Puskesmas Sario Kota Manado" yang menyatakan bahwa mayoritas responden berusia 17-34 tahun yaitu 40 responden (78,4\%). Penelitian Putri (2017) dengan judul "Hubungan Antara Keberadaan Keluarga Anggota Keluarga Yang Merokok Dengan Kejadian Pneumonia Pada Anak Usia 1-4 Tahun Di Wilayah Kerja Puskesmas Tawangsari Sukoharjo" yang menyatakan bahwa mayoritas berusia 3140 tahun yaitu 36 orang (45\%). Penelitian ini juga sejalan dengan penelitian Wulandari, Girsang \& Siagian (2018) dengan judul "Hubungan Ventilasi, Jenis Lantai, Kepadatan Hunian, Dan Kebiasaan Merokok Di Dalam Rumah Dengan Kejadian ISPA Pada Balita Di Kelurahan Sidorejo Hilir Kecamatan Medan Tembung" yang menyatakan bahwa mayoritas responden berumur 31-40 tahun sebanyak 33 orang $(46,5 \%)$. Penelitian ini sejalan dengan teori Sarafino (dalam Sulistyawan, 2012) yang menyatakan bahwa usia mempengaruhi seseorang untuk merokok. Notoatmodjo (2010) juga menyatakan umur seseorang mempengaruhi terhadap daya tangkap dan pola pikir seseorang. Semakin bertambahnya usia akan semakin berkembang pula daya tangkap dan pola pikirnya terhadap kesehatan.

Berdasarkan hasil penelitian, diperoleh data bahwa mayoritas responden pendidikan SMA yaitu 45 orang $(66,2 \%)$. Penelitian ini sejalan dengan penelitian Putri (2017) dengan judul "Hubungan Antara Keberadaan Anggota Keluarga Yang Merokok Dengan Kejadian Pneumonia Pada Anak Usia 1-4 Tahun Di Wilayah Kerja Puskesmas Tawangsari Sukoharjo" yang menyatakan bahwa mayoritas berpendidikan SMA yaitu 39 orang $(48,8 \%)$. Hasil penelitian ini sejalan dengan penelitian Milo, Ismanto \& Kallo (2015) dengan judul "Hubungan Kebiasaan Merokok di Dalam Rumah Dengan Kejadian ISPA Pada Anak Umur 1-5 Tahun Di Puskesmas Sario Kota Manado" yang menyatakan dari hasil penelitian didapatkan responden dengan kebiasaan merokok sebagian besar adalah responden dengan pendidikan SMA yaitu 31 responden $(60,8 \%)$.

Penelitian ini juga sejalan dengan penelitian Pangumpia (2017) dengan judul "Hubungan Perilaku Merokok Di Dalam Rumah Dengan Kejadian Infeksi Saluran Pernapasan Akut (ISPA) Pada Balita Di Puskesmas Sempaja Kota Samarinda" yang menyatakan responden mayoritas berpendidikan SMU sebanyak 67 orang $(52,3 \%)$. Hasil penelitian ini sesuai dengan teori Notoatmodjo (2010) yang menyatakan tentang konsep pendidikan yang merupakan suatu proses belajar yang berarti didalam pendidikan itu terjadi proses pertumbuhan, perkembangan atau perubahan kearah yang lebih dewasa, lebih baik dan lebih matang pada diri individu, kelompok atau masyarakat. Semakin tinggi tingkat pendidikan maka ia akan mudah menerima hal-hal baru dan mudah menyesuaikan hal-hal baru tersebut. Usia mempengaruhi daya tangkap dan pola pikirnya, sehingga pengetahuan yang diperoleh semakin membaik. Pendidikan seseorang mempengaruhi cara berfikir dan bertindak seseorang yang secara aktif mencari berbagai informasi yang ada terutama berkaitan dengan dampak negatif yang ditimbulkan oleh rokok bagi kesehatan.

Berdasarkan hasil penelitian, diperoleh data bahwa mayoritas responden bekerja sebagai pegawai swasta yaitu 32 orang (47,1\%). Hasil penelitian ini tidak 
sejalan dengan penelitian Putri (2017) dengan judul "Hubungan Antara Keberadaan Anggota Keluarga Yang Merokok Dengan Kejadian Pneumonia Pada Anak Usia 14 Tahun Di Wilayah Kerja Puskesmas Tawangsari Sukoharjo" yang menyatakan bahwa bahwa mayoritas ibu rumah tangga yaitu sebanyak 28 orang $(23,2 \%)$. Hasil penelitian ini juga tidak sejalan dengan penelitian Asmidar (2018) dengan judul "Hubungan Kebiasaan Merokok Anggota Keluarga Di Dalam Rumah Dengan Kejadian ISPA Pada Anak Usia 1-5 Tahun Di Puskesmas Asinua Kabupaten Konawe Tahun 2018" yang menyatakan mayoritas responden pekerjaan sebagai ibu rumah tangga sebanyak 38 orang (70,3\%). Penelitian ini juga tidak sejalan dengan penelitian Pangumpia (2017) yang berjudul "Hubungan Perilaku Merokok Di Dalam Rumah Dengan Kejadian Infeksi Saluran Pernapasan Akut (ISPA) Pada Balita Di Puskesmas Sempaja Kota Samarinda" yang menyatakan responden mayoritas bekerja sebagai ibu rumah tangga sebanyak 81 responden $(63,3 \%)$.

Hasil penelitian ini sesuai dengan teori Wawan dan Dewi (2010) yang menyatakan bahwa pekerjaan adalah kebutuhan yang harus dilakukan untuk menunjang kehidupan. Lingkungan pekerjaan dapat menjadikan seseorang memperoleh pengalaman dan pengetahuan baik secara langsung maupun tidak langsung. Teori Sarafino (dalam Sulistyawan, 2012) menyatakan faktor sosiokultural yaitu gengsi pekerjaan dapat mempengaruhi perilaku merokok pada individu. Menurut Halpern, et al (dalam Amalia, 2017) menyatakan status merokok dapat mempengaruhi produktivitas. Rendahnya produktivitas berakibat pada rendahnya tingkat pendapatan yang diterima oleh tenaga kerja.

Peneliti berpendapat bahwa perilaku merokok tersebut timbul akibat dari pengaruh lingkungan. Seseorang dapat terpengaruh oleh rekan kerja yang merokok. Merokok bisa menjadi salah satu kegiatan untuk membuka suatu percakapan dan memperluas pertemanan. Selain itu perilaku merokok juga timbul akibat rokok dapat ditemui dengan mudah di toko-toko kecil sehingga seseorang dengan mudah untuk membeli rokok. Dan pemahaman mengenai bahaya merokok dikalangan masyarakat masih kurang.

\section{Kejadian Infeksi Saluran Pernapasan Akut Pada Balita Di UPTD Puskesmas Tabanan III}

Hasil penelitian ini sejalan dengan penelitian Riyanto \& Kusumawati, (2016) dengan judul "Pengaruh Asap Rokok Terhadap Frekuensi Terjadinya Penyakit ISPA Pada Balita Di Puskesmas Kedung Banteng Banyumas" yang menyatakan bahwa 26 balita $50 \%$ yang terpapar asap rokok $\geq 20$ menit perhari mengalami ISPA lebih sering yaitu $\geq 3$ kali dalam setahun. Hasil penelitian ini sejalan dengan penelitian Maryani (2012) dengan judul "Hubungan Antara Kondisi Rumah dan Kebiasaan Merokok Anggota Keluarga Dengan Kejadian ISPA Pada Balita Di Kelurahan Bandarharjo Kota Semarang" yang menyatakan bahwa dari 78 responden yang mempunyai kebiasaan merokok, ada 47 balita responden menderita ISPA $(66,2 \%)$.

Hasil penelitian ini juga sejalan dengan penelitian Asmidar (2018) yang berjudul "Hubungan Kebiasaan Merokok Anggota Keluarga Di Dalam Rumah Dengan Kejadian ISPA Pada Anak Usia 1-5 Tahun Tahun Di Puskesmas Asinua Kabupaten Konawe Tahun 2018" yang menyatakan bahwa kejadian ISPA pada balita sebanyak 29 orang $(53,7 \%)$. Hasil penelitian ini sesuai dengan teori Irianto (2015) yang menyatakan ISPA merupakan penyakit infeksi akut yang menyerang 
salah satu bagian atau lebih dari saluran napas mulai dari hidung (saluran atas) hingga alveoli (saluran bawah) termasuk jaringan adneksanya seperti sinus, rongga telinga tengah, dan pleura. Hasil penelitian ini juga didukung oleh teori Marni (2014) yang menyatakan usia balita lebih rentan terkena penyakit salah satunya ISPA bila dibandingkan dengan orang dewasa disebabkan karena sistem pertahanan tubuh balita terhadap penyakit masih dalam tahap perkembangan.

Hasil penelitian ini sejalan dengan penelitian Asmidar (2018) dengan judul "Hubungan Kebiasaan Merokok Anggota Keluarga Di Dalam Rumah Dengan Kejadian ISPA Pada Anak Usia 1-5 Tahun Di Puskesmas Asinua Kabupaten Konawe Tahun 2018" yang menyatakan bahwa kebiasaan merokok keluarga didalam rumah sebanyak 34 responden (100\%) dengan kejadian ISPA pada anak usia 1-5 tahun mengalami ISPA sebanyak 25 orang $(73,5 \%)$ dan tidak terjadi ISPA sebanyak 9 orang $(26,5 \%)$. Hasil penelitian ini sejalan dengan penelitian Milo, Ismanto \& Kallo (2015) dengan judul "Hubungan Kebiasaan Merokok di Dalam Rumah Dengan Kejadian ISPA Pada Anak Umur 1-5 Tahun Di Puskesmas Sario Kota Manado" yang menyatakan pada orang tua yang perokok berat ada 12 dari 22 anak $(54,5 \%)$ anak menderita ISPA sedang, dan pada orang tua perokok sedang ada 5 dari 14 anak $(35,7 \%)$ anak menderita ISPA sedang.

Penelitian ini juga sejalan dengan penelitian Wahyuningsih, Raodhah \& Basri (2017) dengan judul "Infeksi Saluran Pernapasan Akut (ISPA) Pada Balita Di Wilayah Pesisir Desa Kore Kecamatan Sanggar Kabupaten Bima" yang menyatakan bahwa terdapat anggota keluarga yang merokok sebanyak 32 responden $(43,35 \%)$ dan rata-rata tempat merokok anggota keluarga adalah didalam rumah. Hasil penelitian ini sesuai dengan teori Irianto (2015) yang menyatakan merokok adalah membakar tembakau kemudian dihisap, baik menggunakan rokok maupun menggunakan pipa. Menurut teori Corwin (2009), anak yang terpajan asap rokok memperlihatkan peningkatan angka ISPA dan penyakit saluran pernapasan lainnya dibandingkan dengan anak-anak dari orang tua bukan perokok.

Peneliti berpendapat bahwa penyakit ISPA dapat disebabkan oleh banyak faktor. Faktor-faktor tersebut jika dibiarkan akan menyebabkan balita dapat menderita ISPA sehingga hal ini harus diimbangi dengan upaya pencegahan terhadap penyakit ISPA. Upaya pencegahan terhadap penyakit ISPA dapat dilakukan dengan menjaga kebersihan baik itu perseorangan atau lingkungan. Bagi orang tua yg merokok sebaiknya mengurangi konsumsi rokok karena dapat menimbulkan efek buruk bagi kesehatan dan diharapkan sebelum menggendong anak sebaiknya pakaiannya diganti karena asap rokok dapat menempel pada baju. Menjaga kebersihan lingkungan juga sangat penting yaitu dengan rajin membersihkan ventilasi rumah dan memperhatikan lingkungan disekitar balita agar terhindar dari asap rokok.

\section{Hubungan Perilaku Merokok Dengan Kejadian Infeksi Saluran Pernapasan Akut Pada Balita Di Puskesmas Tabanan III}

Hasil penelitian ini sejalan dengan penelitian yang dilakukan oleh Syahputra, Sabrian dan Utomo (2014) dengan judul "Perbandingan Kejadian ISPA Balita Pada Keluarga Yang Merokok Di Dalam Rumah Dengan Keluarga Yang Tidak Merokok" yang menunjukkan bahwa 34 keluarga memiliki balita dan anggota keluarga yang merokok didalam rumah 20 balita $(58,8 \%)$ sering terserang ISPA dan hasil analisis data didapatkan nilai $\mathrm{QR}=3,429$ artinya keluarga yang memiliki 
anggota keluarga yang merokok didalam rumah, balita mereka beresiko 3,4 kali terserang ISPA dibandingkan keluarga yang tidak merokok.

Milo, Ismanto dan Kallo (2015) juga menyatakan dalam penelitiannya yang berjudul "Hubungan Kebiasaan Merokok Didalam Rumah Dengan Kejadian ISPA Pada Anak Umur 1-5 Tahun Di Puskesmas Sario Kota Manado", pada orang tua yang perokok berat ada 12 dari 22 anak (54,5\%) anak menderita ISPA sedang, dan pada orang tua perokok sedang ada 5 dari 14 anak $(35,7 \%)$ anak menderita ISPA sedang. Hasil penelitian ini sejalan pula dengan penelitian yang dilakukan oleh Riyanto \& Kusumawati (2016) dengan judul "Pengaruh Asap Rokok Terhadap Frekuensi Terjadinya Penyakit ISPA Pada Balita Di Puskesmas Kedung Banteng Banyumas" dengan hasil penelitian menunjukkan bahwa 26 balita yaitu $50 \%$ yang terpapar asap rokok $\geq 20$ menit per hari dan mengalami ISPA lebih sering yaitu $\geq 3$ kali dalam setahun sedangkan 1 balita $21,15 \%$ yang terpapar asap rokok $<20$ menit per hari jarang mengalami ISPA yaitu $<3$ kali dalam setahun. Hasil penelitian ini sesuai dengan teori Corwin (2009), anak yang terpajan asap rokok memperlihatkan peningkatan angka ISPA dan penyakit saluran pernapasan lainnya dibandingkan dengan anak-anak dari orang tua bukan perokok. Marni (2014) juga menyatakan didalam asap rokok yang dihisap akan mengeluarkan sekitar 4000 bahan kimia berbahaya seperti nikotin, karbonmonoksida dan tar sehingga paparan asap rokok dapat meningkatkan resiko kesakitan pernapasan khususnya pada anak berusia kurang dari 2 tahun. Perjalanan klinis penyakit ISPA dimulai dengan berinteraksinya virus dan kuman yang ada di udara bebas dengan tubuh manusia. Udara bebas banyak mengandung partikel-partikel debu. Gas berbahaya yng terkndung dalam asap rokok merangsang pembentukan lendir, debu dan bakteri. Kerusakan struktur lapiran dinding saluran pernapasan menyebabkan kenaikan aktivitas kelenjar mukus yang banyak terdapat pada dinding saluran napas, sehingga terjadi pengeluaran cairan mukosa yang melebihi normal. Rangsangan cairan yang berlebihan tersebut menimbulkan gejala batuk. Sehingga pada awal gejala ISPA yang paling menonjol adalah batuk.

Berdasarkan hasil penelitian dan teori, peneliti berpendapat bahwa ISPA dapat disebabkan oleh berbagai faktor penyebab, namun dalam penelitian ini menunjukkan bahwa paparan asap rokok memberikan pengaruh besar terhadap serangan penyakit ISPA. Perilaku orang tua balita yang merokok didalam rumah atau disekitar balita dapat menyebabkan balita ataupun orang-orang disekitar perokok menjadi perokok pasif. Hal ini disebabkan karena kurangnya pemahaman keluarga mengenai bahaya merokok tersebut sehingga lebih banyak keluarga yang membawa anaknya ke pelayanan kesehatan dalam keadaan parah.

\section{Simpulan}

\section{SIMPULAN DAN SARAN}

Berdasarkan hasil penelitian diatas disimpulakn terdapat hubungan antara perilaku merokok orang tua dengan infeksi saluran pernapasan akut pada balita di UPTD Puskesmas Tabanan III. Penelitian ini menunjukkan bahwa paparan asap rokok memberikan pengaruh besar terhadap serangan penyakit ISPA 
Bali Medika Jurnal.

Vol 7 No 1, 2020: 11-23

ISSN : 2615-7047

DOI: https://doi.org/10.36376/bmj.v7i1

\section{Saran}

Saran yang dapat diajukan berdasarkan hasil penelitian dan pembahasan adalah sebagai berikut : Kepada orang tua agar dapat meningkatkan pengetahuan seputar bahaya merokok bagi balita, mendukung keluarga untuk tidak merokok di rumah serta membersihkan diri setelah merokok. Kepada petugas kesehatan dapat lebih meningkatkan kegiatan sosialisasi dan edukasi tentang bahaya merokok bagi balita. Kepada peneliti selanjutnya hasil penelitian ini dapat digunakan sebagai bahan referensi untuk penelitian lanjutan dengan menggunakan metode penelitian berbeda. Peneliti selanjutnya agar mengembangkan penelitian ini dengan membedakan secara durasi merokok dengan kejadian infeksi saluran pernapasan akut pada balita.

\section{DAFTAR PUSTAKA}

Amalia, M. N. (2017). Analisis Pengaruh Konsumsi Rokok Terhadap Produktivitas Tenaga Kerja Di Indonesia. Skripsi, 88.

Asmidar, W. (2018). Hubungan Kebiasaan Merokok Anggota Keluarga Di Dalam Rumah Dengan Kejadian ISPA Pada Anak Usia 1-5 Tahun Tahun Di Puskesmas Asinua Kabupaten Konawe Tahun 2018.

Corwin, E. J. (2009). Buku Saku Patofisiologi (3rd ed.). EGC.

Dinas Kesehatan Kabupaten Tabanan. (2017). Profil Kesehatan Kabupaten Tabanan Tahun 2016.

Dinas Kesehatan Provinsi Bali. (2016). Profil Kesehatan Provinsi Bali Tahun 2016.

Ditjen P2PL. (2011). Pedoman Pengendalian Infeksi Saluran Pernafasan Akut. 13.

Friedman, M. M., Bowden, V. R., \& Jones, E. G. (2010). Buku Ajar Keperawatan Keluarga. EGC.

IDAI. (2016, April). Ayah-Bunda, Hati-Hati Dengan Asap.

Irianto, K. (2015). Memahami Berbagai Macam Penyakit. Alfabeta.

Junita, H. (2015). Hubungan Antara Status Merokok Anggota Keluarga Dengan Status ISPA Pada Balita Di Kelurahan Pahandut Kota Palangkaraya.

Kementerian Kesehatan RI. (2013). Situasi Kesehatan Anak Balita Di Indonesia.

Kementerian Kesehatan RI. (2014). Perilaku Merokok Masyarakat Indonesia Berdasarkan Riskesdas 2007 dan 2013.

Kementerian Kesehatan RI. (2017). Profil Kesehatan Indonesia Tahun 2017. 
Bali Medika Jurnal.

Vol 7 No 1, 2020: 11-23

ISSN : 2615-7047

DOI: https://doi.org/10.36376/bmj.v7i1

Lebuan, A. W., \& Somia, A. (2014). Faktor Yang Berhubungan Dengan Infeksi Saluran Pernafasan Akut Pada Siswa Taman Kanak-Kanak di Kelurahan Dangin Puri Kecamatan Denpasar Timur Tahun 2014.

Marni. (2014). Asuhan Keperawatan pada Anak dengan Gangguan Pernapasan. Gosyen Publishing.

Maryani, D. (2012). Hubungan Antara Kondisi Rumah dan Kebiasaan Merokok Anggota Keluarga Dengan Kejadian ISPA Pada Balita Di Kelurahan Bandarharjo Kota Semarang.

Milo, S., Ismanto, A. Y., \& Kallo, V. D. (2015). Hubungan Kebiasaan Merokok di Dalam Rumah Dengan Kejadian ISPA Pada Anak Umur 1-5 Tahun Di Puskesmas Sario Kota Manado.

Notoatmodjo, S. (2010). Ilmu Perilaku Kesehatan. Rineka Cipta.

Novita, N., \& Franciska, Y. (2011). Promosi Kesehatan dalam Pelayanan Kebidanan. salemba medika.

Pangumpia, A. (2017). Hubungan Perilaku Merokok Di Dalam Rumah Dengan Kejadian Infeksi Saluran Pernapasan Akut (ISPA) Pada Balita Di Puskesmas Sempaja Kota Samarinda.

Putri, A. F. (2017). Hubungan Antara Keberadaan Anggota Keluarga Yang Merokok Dengan Kejadian Pneumonia Pada Anak Usia 1-4 Tahun Di Wilayah Kerja Puskesmas Tawangsari Sukoharjo.

Rahayu, I., Yuniar, N., \& Fachlevy, F. (2017). Faktor Yang Berhubungan Dengan Kejadian ISPA Pada Balita Di Wilayah Kerja Puskesmas Soropia Kabupaten Konawe Tahun 2017.

Riyanto, R., \& Kusumawati, A. (2016). Pengaruh Asap Rokok Terhadap Frekuensi Terjadinya Penyakit ISPA Pada Balita Di Puskesmas Kedung Banteng Banyumas. 14.

Rohim, M. M. (2014). Hubungan Merokok Anggota Keluarga Dengan Kejadian Infeksi Saluran Pernapasan Akut (ISPA) Pada Balita Di Wilayah Kerja Puskesmas Paciran Kabupaten Lamongan.

Santoso, Y. A. (2015). Pengaruh Perilaku Merokok Terhadap Kepercayaan Diri Mahasiswa yang Mengikuti Organisasi Intra Kampus UIN Maliki Malang. Universitas Islam Negeri Maulana Malik Ibrahim.

Sulistyawan, A. (2012). Faktor-Faktor yang Berhubungan Dengan Perilaku Merokok Siswa Sekolah Menengah Pertama Negeri 3 Kota Tangerang Selatan Tahun 2012. 
Bali Medika Jurnal.

Vol 7 No 1, 2020: 11-23

ISSN : 2615-7047

DOI: https://doi.org/10.36376/bmj.v7i1

Sutomo, B., \& Anggraini, D. Y. (2010). Menu Sehat Alami Untuk Batita dan Balita (A. Kharie, Ed.). Demedia.

Syahputra, H., Sabrian, F., \& Utomo, W. (2014). Perbandingan Kejadian Ispa Balita Pada Keluarga Yang Merokok Di Dalam Rumah Dengan Keluarga Yang Tidak Merokok. 2.

Wahyuningsih, S., Raodhah, S., \& Basri, S. (2017). Infeksi Saluran Pernapasan Akut (ISPA) Pada Balita Di Wilayah Pesisir Desa Kore Kecamatan Sanggar Kabupaten Bima. 3.

Wawan, A., \& Dewi. (2010). Teori dan Pengukuran Pengetahuan, Sikap dan Perilaku Manusia. Nuha Medika.

Wawan, A., \& Dewi, M. (2012). Teori dan Pengukuran Pengetahuan, Sikap dan Perilaku Manusia. In Syafni. https://doi.org/doi: 10.1023/B:HYDR.0000008590.37567.fa

Wijayaningsih, K. S. (2013). Asuhan Keperawatan Anak. Trans Info Media.

Winarmi, Ummah, B. Al, \& Salim, S. A. N. (2009). Hubungan Antara Perilaku Merokok Orang Tua dan Anggota Keluarga yang Tinggal Dalam Satu Rumah Dengan Kejadian ISPA Pada Balita Di Wilayah Kerja Puskesmas Sempor II Kabupaten Kebumen Tahun 2009.

Wulandari, W., Girsang, E., \& Siagian, M. (2018). Hubungan Ventilasi, Jenis Lantai, Kepadatan Hunian, Dan Kebiasaan Merokok Di Dalam Rumah Dengan Kejadian ISPA Pada Balita Di Kelurahan Sidorejo Hilir Kecamatan Medan Tembung. 